\title{
Una nueva imagen de la Ley: Deleuze y la jurisprudencia
}

\author{
Alexandre Lefebvre \\ Trad. Torres Gabriel \\ UNNE- S.G.C.yT.
}

Gilles Deleuze criticó repetidamente a las leyes de la naturaleza, a la ley natural, a las leyes morales, y a leyes jurídicas, las cuales juntas forman una crítica a lo que llamo la imagen dogmática de la ley. Esta imagen sofoca los devenires, y así la filosofía de Deleuze podría comprenderse en tanto orientada por una crítica de la ley y por la creación de conceptos no-legales (tales como diferencia, repetición, y desterritorialización) capaces de derribar el dominio de la ley y de ser instaurados como su condición. Sin embargo, al mismo tiempo Deleuze también nos ha dejado provocativas observaciones sobre la jurisprudencia, una institución que él valora por ser capaz de proveer escapes y fugas de la ley. Este ensayo toma los comentarios de Deleuze sobre la jurisprudencia y desarrolla una teoría positiva del derecho. A tal fin, la jurisprudencia requiere una concepción de la ley capaz de operar creativamente; exige una ley que funcione positiva e inmanentemente al combinar su propia historia (en la forma de precedentes y legislaciones) con los puntos singulares de un caso legal.

Palabras claves: Deleuze, Bergson, ley, jurisprudencia, juicio, adjudicación

Gilles Deleuze repeatedly criticized laws of nature, natural law, moral laws, and juridical laws, together forming a critique of what I term the dogmatic image of law. The dogmatic image of law stifles becomings, and Deleuze's philosophy may be understood as driven by a critique of law and by the creation of non-legal concepts (such as difference, repetition, and deterritorialization) able to overturn the rule of law and be instated as its condition. At the same time, however, Deleuze also left us with provocative remarks on 
jurisprudence, an institution he values as able to provide escapes and flights from law. This essay takes Deleuze's comments on jurisprudence and develops a positive theory of law. To this end, jurisprudence requires a conception of law capable of operating creatively; it demands a law that functions positively and immanently by combining its own history (in the form of precedents and statutes) with the singular points of a legal case.

Keywords: Deleuze, Bergson, law, jurisprudence, judgment, adjudication

\title{
Una nueva imagen de la Ley: Deleuze y la jurisprudencia*
}

\author{
Alexandre Lefebvre ${ }^{1}$ \\ University of Sydney (Australia) \\ Actuar por la libertad, devenir revolucionario, en efecto, es operar dentro de la \\ jurisprudencia. \\ - Gilles Deleuze, El Abecedario
}

\section{Jurisprudencia: Hacia una nueva imagen de la ley}

Gilles Deleuze nos ha dejado una serie de sugestivas observaciones sobre la jurisprudencia. Constantemente en sus escritos Deleuze rechaza la ley in toto, en tanto abstracta, moralizante y limitativa. Sin embargo, en una entrevista sostiene que "lo que crea derecho no son los códigos ni las declaraciones sino la jurisprudencia. La

\footnotetext{
* Publicado originalmente en Telos. Critical theory of the Contemporary. Primavera 2005, Nueva York, Telos Press, Vol 2005, № 130, pp. 103-126.

${ }^{1}$ Agradezco a Melanie White por su vasta ayuda con este artículo y con sus conceptos, y a Paola Marrati por sus seminarios sobre Deleuze y por su cuidadosa lectura de este escrito.
} 
jurisprudencia es la filosofía del derecho y procede mediante singularidades, por prolongación de singularidades." ${ }^{2}$ En otra conversación, esta vez con Antonio Negri, Deleuze traza una distinción crítica entre ley y jurisprudencia: "no me interesan ni la ley [la loi] ni las leyes [les lois] (la primera es una noción vacía, las otras son nociones cómplices), ni siquiera el derecho o los derechos, lo que me interesa es la jurisprudencia. Ella es la verdaderamente creadora de derecho: habría que evitar que los jueces la monopolicen." ${ }^{3}$ La jurisprudencia se precia de poder desbloquear los movimientos que la ley detiene; es elogiada como una institución capaz de hacer honor a la situación singular, en contraste con las limitaciones de los "derechos del hombre" y otros valores eternos y vacíos. ${ }^{4}$ Podríamos llamar al modo en que opera la jurisprudencia como una línea-de-fuga institucionalizada, un poder autorizado pero también desterritorializador, que "hace que lo adquirido corra siempre el riesgo de volver a ser cuestionado...". En síntesis, la jurisprudencia es un positivo escape de las restricciones de la ley.

Inspirándome en los comentarios de Deleuze sobre la naturaleza de la jurisprudencia evaluaré las posibilidades de una filosofía del derecho deleuziana. ${ }^{6} \mathrm{El}$

\footnotetext{
2 Gilles Deleuze, Negotiations, 1972-1990, tr. by Martin Joughin (New York: Columbia University Press, 1995), p. 153. [Existe versión castellana: DELEUZE, Gilles, Conversaciones. 1972-1990. Trad. José Luís Pardo. Valencia, Pre-Textos, 1996, p. 243]

${ }^{3}$ Ibíd., p. 169. Énfasis añadido. [lbíd., p. 266.] Además de estos dos comentarios sobre jurisprudencia, la entrada 'G' de El Abecedario de Deleuze es valiosa por su consideración extensa y concreta sobre la ley, la justicia y la jurisprudencia institucional. Gilles Deleuze, L'Abecedaire de Gilles Deleuze, avec Claire Parnet, (Paris:DVD Editions Montpamasse, 2004). [Existe una traducción al castellano realizada por Raúl Sánchez Cedillo, disponible en diversos sitios virtuales. Ver http://anarquiacoronada.blogspot.com.ar/2015/04/obras-completas-de-gilles-deleuze.html?view=mosaic. También existe una traducción al español realizada por el "Centro de Estudio e Investigación en Medicina y Arte" de Rosario, Argentina. CENTRO DE ESTUDIO E INVESTIGACION EN MEDICINA Y ARTE, "Abecedario de Gilles Deleuze", 29-06-2016. http://www.medicinayarte.com/pages/ver/deleuze_abecedario_1988_mya (N de T.)]

${ }^{4}$ Deleuze, Negotiations, op. cit., p. 122. [DELEUZE, Gilles, Conversaciones. Op. Cit., p. 194]

${ }^{5}$ Ibid., p. 153. [lbíd., p. 243]

${ }^{6}$ Hasta el momento, no ha habido ningún estudio consistente y prolongado sobre Deleuze en términos de una filosofía del derecho. Patton comienza hábilmente tal proyecto en el último capítulo de su libro Deleuze y lo Político pero resulta más bien un gesto y una dirección sugerida antes que un proyecto de largo plazo. Ver Paul Patton, Deleuze and the Political (New York: Routledge, 2000) [Existe traducción castellana: PATTON, Paul, Deleuze y lo Político. Trad. Margarita Costa. Buenos Aires, Prometeo, 2013]. Si bien existen agudos estudios sobre filosofía del derecho vis-a-vis deconstrucción (ver Drucilla Cornell, The Philosophy of the Limit (New York: Routledge, 1992)); dialéctica hegeliana (ver Jeanne L. Schroeder, The Vestal and the
} 
propósito de este artículo es sostener que, a pesar de su implacable crítica a la ley, Deleuze nos ofrece conceptos capaces de crear una filosofía positiva de la ley jurídica. Esto altera el modo en que comprendemos la relación de Deleuze con la ley, pero lo que es más importante es que también altera la manera en que comprendemos la ley y la jurisprudencia. Desarrollaré esto a partir de tres grandes pasos: 1. Comienzo detallando la crítica de Deleuze a la ley, dividiéndola en cuatro temas básicos: la crítica de la falsa repetición que convierte singularidades en particularidades regidas por la ley general; la crítica de la diferencia distributiva y equívoca, distribuida por juicios de buen sentido y sentido común; la crítica de la ley moral en tanto centrada en el Estado; y la crítica de los derechos humanos por abstractos. Aunque estas críticas pueden parecer distintas, juntas constituyen un coordinado rechazo de lo que llamo la imagen dogmática de la ley. Seguido a esto, se verá que Deleuze aporta conceptos expresamente designados para reemplazar la ley e instituir la verdadera diferencia, la verdadera repetición, y la verdadera acción política: la verdadera repetición será concebida como la extra-legalidad par excellence. Deleuze insistirá en haber acabado con el juicio. La filosofía política comenzará sólo con la subversión irónica o humorística de la ley; y los derechos humanos habrán de reemplazarse por usuarios-grupos y por específicas intervenciones de jurisprudencia. Esto nos permite caracterizar preliminarmente el proyecto filosófico y político de Deleuze como de "lex versus jus."7 Así, los comentarios de Deleuze sobre jurisprudencia pueden ser

Fasces (Berkeley: University of Califomia Press, 1998)); pragmatismo formal (ver Jurgen Habermas, Between Facts and Norms: Contributionsto a Discourse Theory of Law and Democracy, tr. by William Rehg (Cambridge: MIT Press, 1998)); y psicoanálisis (ver Peter Fitzpatrick, Modernism and the Grounds of Law (Cambridge: Cambridge University Press, 2001)); Peter Goodrich, OedipusLex: Psychoanalysis, History, Law (Berkeley, CA: University of Califomia Press, 1995); and Pierre Legendre, Le desir politique de Dieu: etude sur les montages de l'etat et du droit (Paris: Fayard, 1988), no se han llevado a cabo estudios comparables con la filosofía deleuziana (con excepción del poco amable capítulo de Dialectic of Nihilism:Post-Structuralism and Law de Gillian Rose (Oxford: Basil Blackwell, 1984)). Tal ausencia es sorprendente dado que los temas que Deleuze expuso a lo largo de toda su obra -repetición compleja, producción de sentido y creatividad- se ajustan perfectamente a una renovada comprensión de la filosofía de la ley, del juicio y de la jurisprudencia. ${ }^{7}$ Michael Hardt, Gilles Deleuze, an Apprenticeship in Philosophy (Minneapolis: University of Minnesota Press, 1993), p. 23. [Existe versión castellana: HARDT, Michael, Deleuze. Un aprendizaje filosófico. Trad. Alcira Bixio. Buenos Aires, Paidós, 2005. p. 27] 
comprendidos como una minuciosa crítica y reemplazo de la ley científica, natural, moral, y jurídica.

2. Tras delinear la crítica a la ley, detallo el funcionamiento del mecanismo de jurisprudencia deleuziana. Tal como lo han señalado comentadores de Deleuze, la ley y la jurisprudencia no deben operar en una estricta oposición sino juntas, ya que la ley crea el axioma que la jurisprudencia captura caso por caso. ${ }^{8}$ Así, el caso llega a señalar el sitio de acople entre ley y jurisprudencia. En lo que sigue me baso fuertemente en Henri Bergson -y en los comentarios de Deleuze sobre Bergson, junto con su mandato de renovar y extender los conceptos bergsonianos hacia nuevas ciencias ${ }^{9}-$ a fin de construir el caso legal como una imagen material, y el archivo legal de casos y decisiones previas como virtualmente existente. Desde esta perspectiva, la jurisprudencia es caracterizada como una actualización positiva; es la resonancia entre la singularidad del caso y la virtualidad del archivo legal. Tras analizar la jurisprudencia accedemos a una nueva imagen de la ley, y no a su descrédito absoluto.

3. Al describir el proceso de la jurisprudencia, arribo a varias especificaciones sobre la nueva imagen de la ley, especificaciones suscitadas pero no concretadas por Deleuze. Primero, una noción de la ley debidamente concebida no es axiomática ni abstracta. Antes bien, la ley vive sólo en las inventivas actualizaciones de la jurisprudencia (la vida de la ley). Segundo, una ley cobra sentido y logra una determinación sólo a través de problemas. Un caso no es sino un problema sobre la ley y su sentido. Ni el caso ni la ley pueden determinarse a sí mismos sin la constelación del otro (el problema de la ley).

\footnotetext{
${ }^{8}$ Daniel W. Smith, "Deleuze and the Liberal Tradition: Normativity, Freedom, and Judgement," en Economy and Society 32, no. 2 (2003): 299-324, p. 313. El artículo de Smith es una reseña del libro de Patton Deleuze y lo Político, libro cuya valiosa contribución consiste en presentar un preliminar bosquejo de la jurisprudencia deleuziana, específicamente en torno a cuestiones relativas al derecho aborigen en Australia y a la creación de un jurisprudencial "espacio liso" entre las tradiciones de códigos legales comunes e indígenas, superponiendo y desterritorializando cada código en el otro. Ver Patton, Deleuze and the Political, op. cit., pp. 122-131. [PATTON, Paul, Deleuze y lo Político. Op cit, pp. 175-184]

9 Ver el "Epílogo" de Deleuze a la edición inglesa de El Bergsonismo, tr. Hugh Tomlinson y Barbara Habberjam (New York: Zone Books, 1991), p. 115. [Existe traducción castellana: DELEUZE, Gilles, "Epílogo a la edición americana: un retorno a Bergson", en DELEUZE, Gilles, Dos regímenes de locos. Textos y entrevistas (1975-1995). Trad. José Luis Pardo. Valencia, Pre-Textos, 2007, p. 301]
} 
Tercero, si la ley existe sólo en sus actualizaciones, una pura virtualidad inactual de la ley debe ser presupuesta en la forma de un archivo legal ontológicamente existente, aunque indeterminado. La génesis de un juicio se sitúa no entre actuales -casos presentes y leyes conocidas- sino entre lo virtual y su actualización (el pasado de la ley). Cuarto, la ley así concebida no se opone sino que asegura la jurisprudencia (presuposición jurisprudencial de la ley). Quinto, la ley es inherente y técnicamente creativa. La ley se muestra sólo en una particular repetición de la singularidad del caso y de la especificación del archivo jurídico (la creatividad de la ley). A través de estos cinco puntos Deleuze formula un concepto coherente y positivo de la ley jurídica.

\section{Critica de la imagen dogmática de la ley}

Denomino "imagen dogmática de la ley" a un grupo de cuatro características interrelacionadas -repetición falsa, diferencia distributiva, centralidad del Estado y abstracción- que al unirse forman una figura que previene la aparición de la auténtica diferencia y repetición. Por lo tanto, no es menor que Diferencia y repetición comience, y que esté organizada, por una crítica de la ley, y que ésta sea sistemáticamente extendida en Mil Mesetas. A continuación presento cuatro críticas a la imagen dogmática de la ley y su reemplazo por términos extra-legales que hacen justicia a la verdadera diferencia y a la verdadera repetición.

\section{Singular $\rightarrow$ Particular (crítica de la repetición falsa).}

Una ley es un conjunto de relaciones constantes. Su operación primordial consiste en determinar una semejanza entre los sujetos a los que somete vis-a-vis los términos que ella designa. ${ }^{10}$ La formulación de una ley requiere la extracción de constantes o -lo que es lo mismo- una determinación de variables pertenecientes a otra ley. Para Deleuze lo

\footnotetext{
${ }^{10}$ Gilles Deleuze, Difference and Repetition, tr. by Paul Patton (New York: Columbia University Press, 1994), p. 2. [Hay versión castellana: DELEUZE, Gilles, Diferencia y repetición. Trad. María Silvia Delpy y Hugo Beccacece. Buenos Aires, Amorrortu, 2002, p. 22]
} 
fundamental es que la ley compele a las singularidades a cambiar: pasan de ser singularidades a particulares. En vez de poseer su propia diferencia singular en combinación con otras singularidades, la ley transforma lo singular en una particular ilustración de una ley general en relación con otros particulares que también ilustran leyes. Esta conversión a particularidad excluye la verdadera repetición diferencial de singularidades: "Forma vacía de la diferencia, forma invariable de la variación, la ley exige que sus sujetos no cumplan con ella más que al precio de sus propios cambios." ${ }^{11}$

Este concepto de ley impide considerar lo singular y su diferencia. Resulta dogmático por dos motivos. Primero, las singularidades se producen para asemejarse entre sí como particulares subsumidos por una ley idéntica. Segundo, las leyes mismas mantienen relaciones fijas con otras leyes, haciendo del cambio una repetición calculable. La singularidad comparece ante una ley que la modifica en su tipo; descubre que su íntima subjetividad legal es de hecho expresión de una ley, y que su impotencia es simplemente su forma legal objetiva: "un sujeto de la ley experimenta su propia impotencia para repetir y descubre que esta impotencia ya está comprendida en el objeto, reflejada en el objeto permanente en el que lee su condenación." ${ }^{12}$ La forma legal aprisiona la singularidad al constituirla como un particular legal regular; al hacerlo, la ley separa a lo singular de lo que puede hacer. Poderes creativos y estrictamente imprevisibles son sustituidos por la forma legal de generalidad/particularidad.

Por tales motivos, la auténtica repetición denuncia la relación de la ley con sus particulares en provecho de la repetición diferencial de lo singular. La repetición es la extra-legalidad misma, por doquier pone a la ley en tela de juicio: "[La repetición] está contra la ley: contra la forma semejante y el contenido equivalente de la ley. Si la repetición puede ser hallada, aún en la naturaleza, lo es en nombre de una potencia que se afirma contra la ley, que trabaja por debajo de las leyes, que puede ser superior a ellas." ${ }^{13}$ Más aún, como Deleuze sostiene más adelante en Diferencia y Repetición, la

\footnotetext{
${ }^{11}$ Ibid., p. 2. [lbíd., pp. 22-23]

${ }^{12}$ Ibid., p. 2. [lbíd., p. 23]

${ }^{13}$ Ibid., p. 2. Énfasis añadido. [lbíd., p. 23]
} 
repetición genética y positiva de singularidades da lugar al orden legal, un orden que entonces confunde la verdadera génesis de las singularidades al representarlas como particularidades legales. Mi propósito no es bosquejar exhaustivamente la repetición auténtica según Deleuze, sino simplemente indicar que está expresada en afirmaciones categóricamente anti-legalistas.

\section{Diferencia Distributiva (crítica del juicio)}

La crítica de la diferencia distributiva en Diferencia y Repetición es una crítica de la diferencia específica y genérica de Aristóteles. La mayor y más perfecta diferencia es para Aristóteles la diferencia "específica", situada entre las especies que comparten un género. Al interior del género, la diferencia es unívoca: las muchas especies diferentes se dicen en un sólo y mismo sentido de su género. Este último es capaz de albergar diferencias permaneciendo sustancialmente idéntico, "[el género] permanece él mismo para sí volviéndose a la vez otro en las diferencias que lo dividen." ${ }^{14}$ Esto no es el caso de la diferencia genérica. Aquí, las diferencias entre géneros son equívocas; sus diferencias son demasiadas vastas para caber en relaciones de contrariedad específica y no pueden ser reunidas en una identidad que las contenga. ${ }^{15}$

Según Deleuze, este esquema específico/genérico es una tímida concepción que confisca la verdadera naturaleza de la diferencia. Al mismo tiempo la verdadera universalidad se pierde en la equivocidad y la verdadera singularidad se desvanece en provecho de semejanzas entre diferencias específicas. ${ }^{16}$ Este concepto de diferencia tiene significativas consecuencias para el juicio. La diferencia genérica es equívoca, y como tal no es colectiva sino distributiva. Una lista de categorías (las más amplias divisiones) viene a representar al ser y establece una "distribución sedentaria, en la que hay una partición fija de algo distribuido, según una proporcionalidad fijada por la regla." ${ }^{17}$ Aquí, el juicio

\footnotetext{
${ }^{14}$ Ibid., p. 31 [Ibíd., p. 65]

${ }^{15}$ Ibid., p. 34 [lbid., p. 67]

${ }^{16}$ Ibid., p. 38 [lbid., p. 70]

${ }^{17}$ Ibid., p. 303 [lbíd., p. 416]
} 
divide y reparte el concepto en los términos de aquello que es afirmado; distribuye al Ser en diferencias categóricas y procede a subsumir diferencias específicas bajo estas categorías. Esta actividad preserva la identidad dentro del juicio, es por ella que "un concepto idéntico o común subsiste todavía.. ${ }^{18}$ El juicio categórico asigna a cada ser un lugar en el Ser, reparte un territorio en dominios particulares ordenado por divisiones de diferencias genéricas y específicas.

De este modo el juicio impide cualquier aparición de la diferencia interna, o de diferencias entre cosas de la mismo tipo (sea entre existentes o dentro del existente mismo). El juicio es una doble operación establecida sobre el sentido común (la repartición equívoca de las varias categorías y su coordinación) y el buen sentido (exacta distribución empírica en categorías); ambos valores "constituyen la justa medida [la juste mesure], la 'justicia' como valor del juicio." ${ }^{19}$ Subyaciendo al juicio se encuentra la presuposición de que categorías existentes pueden repartir la diferencia adecuadamente; es precisamente esta presuposición lo que asegura que el juicio "no puede aprehender lo que hay de nuevo en un existente, ni siquiera presentir la creación de un modo de existencia." ${ }^{20} \mathrm{Si}$ el juicio aprehende un "nuevo" ser discreto, el esquema será redefinido con distinciones más finas, pero la forma del juicio y la diferencia distributiva permanecerán obviamente intactas. Por eso mismo, haciéndose eco de Artaud Deleuze recomienda "acabar con el juicio," abandonar la diferencia distributiva en provecho de un nomos nomádico. ${ }^{21}$ Tal espacio liso sucede cuando las diferencias mismas (y no según un plan decretado) se distribuyen en un espacio abierto que socava la totalidad del juicio. Aquí, los seres van hasta el límite y umbral de su poder, y al hacerlo se transforman y se diferencian ellos mismos. Las leyes de buen sentido y sentido común son derrumbadas en el rechazo al juicio que ocasiona el nomos nomádico.

\footnotetext{
${ }^{18}$ Ibid., p. 33 [lbíd., p. 68]

${ }^{19}$ Ibid., p. 33. [lbid., p. 69]

${ }^{20}$ Gilles Deleuze, Essays Critical and Clinical, tr. by Daniel W. Smith and Michael A. Greco (Minneapolis: University of Minnesota, 1997), p. 134. [Existe versión al español: DELEUZE, Gilles, "Para acabar de un vez con el juicio" en Crítica y clínica. Trad. Thomas Kauf. Barcelona, Anagrama, 1996, p. 188.]

${ }^{21}$ Deleuze, Difference and Repetition, op. cit., p. 36. [DELEUZE, Gilles, Diferencia y repetición. Op cit., p. 73]
} 


\section{Ley Moral (crítica de la forma estado)}

En Diferencia y Repetición, la ley moral funciona de modo análogo a las leyes de la naturaleza, convirtiendo singularidades en particulares. La ley moral es reconocida en una 'prueba' de repetición, una prueba de los tipos de hábitos y conductas que pueden repetirse por principio sin generar contradicción, a diferencia de las repeticiones demoníacas y del tedio de la existencia estética. ${ }^{22}$ Con la ley moral permanecemos en el ámbito de la generalidad, donde deseos y acciones singulares son convertidos -testeadosen particularidades repetibles de una ley moral general. ${ }^{23}$ Tal operación es una recuperación del sentido común (distribución de diferentes acciones acordes a un esquema moral establecido) en el plano de la razón práctica.

El análisis de esta prueba moral es profundizado en Mil Mesetas, anticipando la forma de la ley estatal. La ley moral es una extraña subrepción donde la sumisión a la ley obtiene auto-dominio y mando: "Obedeced siempre, pues, cuanto más obedezcáis más dueño seréis puesto que sólo obedeceréis a la pura razón, es decir, a vosotros mismos...". ${ }^{24}$ Esto se encuentra a sólo un paso de distancia de una república de sujetos autolegisladores, reunidos por la razón y por el contrato, donde “...la razón realizada se confunde con el Estado de derecho [I'Etat de droit], al igual que el Estado de hecho es el devenir de la razón." ${ }^{25}$ Un Estado de Naturaleza putativo significa un oprobio estético, y la participación en un pacto autolegislado equivale a una unión de libertad y razón. El Estado es nada más la forma de la razón pura y práctica, una actualización política de las facultades y la unión del sentido común y el buen sentido. ${ }^{26}$

\footnotetext{
${ }^{22}$ Ibid., p. 4. [lbíd., p. 25.] Para esto Deleuze tiene en mente al Kierkegaard de las Éticas I o II.

${ }^{23}$ Ibid., pp. 4-5. [lbíd, pp. 26-27]

${ }^{24}$ Gilles Deleuze and Félix Guattari, A Thousand Plateaus, Capitalism and Schizophrenia, tr. by Brian Massumi (Minneapolis: University of Minnesota Press, 1987), p. 376. [Existe versión castellana: DELEUZE, Gilles, y GUATTARI, Félix, Mil Mesetas. Capitalismo y Esquizofrenia. Trad. José Vázquez Pérez y Umbelina Larraceleta. Valencia, Pre-Textos, 2006, p. 381]

${ }^{25}$ Ibid., pp. 375-6. [lbíd., p. 380]

${ }^{26}$ Ibid., p. 375. [lbíd., p. 380]
} 
La ley moral no sólo sanciona y sostiene la forma estatal general de la asociación contractual política (como sentido común), sino que además apuntala la ley jurídica del estado (buen sentido). El "crimen," por ejemplo, es buen sentido abusado: es una violencia juzgada ilegal por que consiste en apoderarse de "algo a lo que no se tiene ‘derecho.'”27 El crimen es una corrupción de la armonía de las facultades en la medida en que uno se comporta mal (fracasa en la prueba de la repetición moral; el crimen no es generalizable) y reclama por fuera de su provincia. Por el contrario, la ley moral (y su buen sentido y sentido común doblemente articulados) establece una violencia legítima, capturando a la vez que "constituye un derecho de captura." ${ }^{28}$ La captura legítima sanciona el uso de violencia según una establecida armonía de las facultades (de asuntos del Estado y de la paz), que constituye su dominio denominando "criminal" a aquello que no respeta sus ordenamientos. Tal operación legal forzosamente "particulariza" singularidades aberrantes.

La ley moral sirve para sofocar los devenires: su prueba convierte singularidades en particularidades, anticipa el Estado contractual de legislación universal, y establece dominios de derecho y de criminalidad. Si la sociedad (y a forteriori la sociedad política) es definida por líneas de fuga, entonces la ley moral es pura obstrucción. ${ }^{29}$ Ese es el motivo por el cual para Deleuze el término ley moral no forma parte del discurso político. De hecho, es la desterritorialización de la ley (moral) lo que hace posible la filosofía política. En Lo frío y lo cruel Deleuze analiza cómo la ley es derrumbada a través de procesos de ironía y humor. Por ejemplo, el principio político Irónico de Platón es que la misma ley es un poder secundario que depende de un principio del Bien; igualmente, la obediencia a la ley es "lo mejor", y lo mejor es la simple imagen humorística del Bien: "esta imagen, en apariencia tan conformista, encierra sin embargo un ironía y un humor que constituyeron las condiciones de una filosofía política, un doble margen de reflexión, arriba y abajo en la

\footnotetext{
${ }^{27}$ Ibíd., p. 448 [lbíd., p. 454]

${ }^{28}$ Ibid., p. 448 [lbíd., p. 454]

${ }^{29}$ Ibid., p. 171 [Ibíd., p. 165]
} 
escala de la ley." ${ }^{30}$ Este examen va hasta Sade (quien ironizó a la ley como secundaria respecto al modelo institucional de la anarquía) y Masoch (quien humorizó a la ley mediante el desorden y el placer masoquista que surge de adherir minuciosamente a sus prohibiciones). Mi intención no es relatar en detalle este complejo análisis sino, insisto, indicar que la ley resulta desestimada (o, más bien, desterritorializada) a favor de términos extra-legales; como tales, el humor y la ironía subtienden la posibilidad de un pensamiento social y político y de una verdadera aprehensión de movimientos y deseos.

\section{Derechos humanos (crítica de la abstracción)}

Los documentos de derechos humanos son abstractos en sus expresiones al suministrar condiciones generales que protegen la vida, la libertad, la opinión, la propiedad, etc. Una constitución, o cualquier catálogo de derechos humanos, agrupa proposiciones fluctuantes vacías de sentido. Adaptando el argumento de Deleuze de Lógica del Sentido, podemos decir que las proposiciones están desprovistas de sentido mientras no se refieran a una situación concreta -un problema- que genera su sentido y su condición. ${ }^{31}$ Es incorrecto decir que los derechos simplemente requieren una denotación en una situación específica que habrá de informar al derecho si es verdadero o falso (i. e., denotación cumplida si el derecho es respetado, o denotación infeliz si el derecho es violado). Los derechos necesitan mucho más: requieren situaciones concretas no sólo para denotar sino también para cobrar sentido. Valores abstractos como la libertad o la propiedad exigen una situación concreta - ¿qué clase de libertad es garantizada?, ¿qué efectos de la opinión pueden limitar su uso?, ¿qué clase de propiedad deben ser protegidas? La insistencia formal resulta vacía porque sin el caso particular y la situación concreta, los derechos no nos dicen nada y son incapaces de realizar justicia.

\footnotetext{
${ }^{30}$ Gilles Deleuze, "Coldness and Cruelty," in Masochism (New York: Zone, 1989), p. 81. Enfasis añadido. [Hay versión al español: DELEUZE, Gilles, Presentación de Sacher Masoch. Lo frío y lo cruel. Trad. Irene Agoff. Buenos Aires, Amorrortu, 2001, p. 85]

${ }^{31}$ Gilles Deleuze, The Logic of Sense, tr. by Mark Lesser (New York: Columbia University Press, 1990), pp. 1222 and 121-23. [Existe versión castellana: DELEUZE, Gilles, Lógica del sentido. Trad. Miguel Morey y Víctor Molina. Buenos Aires, Paidós, 2005, pp. 35-45 y 134-136]
} 
Como lo señaló Alain Badiou, los derechos humanos fracasan en incumbir directamente a los individuos (en tanto multiplicidades concretas) al referir a un sujeto humano general, de modo tal que sea cual sea el "mal que lo afecte sea universalmente identificable." ${ }^{32}$ En este sentido, Deleuze coincide con Badiou al sostener que los derechos son axiomáticos y generales, coexistiendo en un espacio de múltiples axiomas tales como la protección de la propiedad, derecho a la guerra, etc. Estos axiomas existen juntos en un entorno competitivo; uno puede invalidar otro, y postular abstractamente "nada dicen los derechos del hombre sobre los modos de existencia inmanentes del hombre provisto de derechos." ${ }^{\prime 33}$ Hasta que ingresan en agenciamientos y determinaciones concretas, los derechos permanecen como un mero elemento técnico en máquinas sociales más amplias de diversos axiomas con variados valores: "El principio de todo tecnología es mostrar cómo un elemento técnico continúa siendo abstracto, totalmente indeterminado, mientras que no se le relacione con un agenciamiento [agencement] que él supone.."34 Los derechos no garantizan en absoluto la protección de la vida; junto con otros axiomas son partes esenciales del capitalismo liberal y, como tales, algunos derechos (de propiedad, por ejemplo) pueden enfrentarse a otros (derecho a la vida, por ejemplo).

Por estos motivos Deleuze recomienda que la jurisprudencia se dirija a específicos grupos de usuarios que negocien cómo vivir con un problema. En vez de un sujeto portador de derechos general y transcendente, tenemos la vida y los problemas de la vida que proceden sólo caso-por-caso, algo que corresponde a la jurisprudencia desentrañar y dignificarlo. ${ }^{35}$ La jurisprudencia se dirige a una situación para hacerla soportable, se resiste

\footnotetext{
${ }^{32}$ Alain Badiou, Ethics: An Essay on the Understanding of Evil, tr. by Peter Hallward (London: Verso, 2001), p. 9, [Existe traducción castellana: BADIOU, Aalin, La ética. Ensayo sobre la conciencia del mal. Trad. Raúl J. Cerdeiras. México, Herder, 2004, p. 33] y Alain Badiou, D'un desastre obscur: droit, état, politique (Paris: Editions de L'Aube, 1991). [Hay versión en español: BADIOU, Alain, De un desastre oscuro. Sobre el fin de la verdad de Estado. Buenos Aires, Amorrortu, 2006]

${ }^{33}$ Gilles Deleuze and Félix Guattari, What Is Philosophy? tr. by Hugh Tomlinson and Graham Burchell (New York: Columbia University Press, 1994), p. 107. [Existe versión en español: DELEUZE, Gilles, y Guattari, Félix, ¿Qué es la filosofía? Trad. Thomas Kauf. Barcelona, Anagrama, 1993, p. 109]

${ }^{34}$ Deleuze and Guattari, $A$ Thousand Plateaus, op. cit., pp. 397-398. [Deleuze, Gilles, y Guattari, Félix, Mil Mesetas. Op, cit, p. 400]

${ }^{35}$ Deleuze, L'Abecedaire, op. cit., G.
} 
a cifrarla en evaluaciones trascendentes relativas al abuso. La Justicia y los Derechos no existen. Sólo la jurisprudencia existe y ella sola es capaz de crear derecho [droit]. ${ }^{36}$

Ahora vemos las cuatro importantes críticas de Deleuze a la ley: la ley convierte singularidades en particularidades que fatalmente comprometen la repetición; el juicio distributivo impone un esquema ordenador de diferencia genérica y específica; la ley moral se modela ella misma a partir del sentido común y el buen sentido, anticipando el advenimiento del estado; y los derechos humanos son abstractos, incapaces de clarificar o brindar justicia a situaciones concretas. Igualmente, Deleuze crea conceptos expresamente extraños a la ley y al orden legal -repetición extra-legal; un nomos nomádico para librar al pensamiento del juicio; humor e ironía para colapsar la ley; jurisprudencia y grupos de usuarios para reemplazar los derechos- situando así su filosofía como una vasta empresa contra la ley.

\section{Dos encuentros}

Sin embargo, una nueva imagen de la ley, una no dogmática, puede discernirse dentro del corpus de Deleuze. Es su particular lectura de Bergson, especialmente su atención a la relación entre lo virtual y lo actual, lo que hace posible esto. Las implicaciones son profundas, ya que alude a las condiciones de la experiencia real. Por ejemplo, mientras que la imagen dogmática de la ley asume que los derechos humanos son la condición capaz de identificar y atender todas las posibles violaciones del derecho, una nueva imagen de la ley, por el contrario, sigue una inspiración bergsoniana e indaga no en las condiciones de toda experiencia legal posible, sino que apunta a "las condiciones de la experiencia real." ${ }^{37}$ Una nueva imagen de la ley debe alcanzar la manifestación individual de la ley, la génesis de la ley, su sentido y aplicación. Si para Deleuze el primer

\footnotetext{
${ }^{36}$ Ibid., G.

${ }^{37}$ Gilles Deleuze, "Bergson's Conception of Difference," in Desert Islands, and Other Texts, 1953-1974, ed. by David Lapoujade, pp. 32-51 (Los Angeles: Semiotext(e), 2004), p. 36. [Existe versión castellana: DELEUZE, Gilles, "La concepción de la diferencia en Bergson" en La isla desierta y otros textos. Textos y entrevistas (1953-1974). Trad. José Luis Pardo. Valencia, Pre-textos, 2005, p. 42]
} 
principio de la filosofía es que los universales "no explican nada, tienen que ser explicados a su vez," una nueva imagen de la ley debe seguir este viraje y analizar, con precisión, cómo la ley funciona, cuáles son sus condiciones de emergencia, y cómo habrá de forjar un concepto que proteja contra las ofuscaciones legales que Deleuze criticó implacablemente. $^{38}$

Considero que la primera condición para una nueva imagen de la ley es basar su emergencia sobre la noción de un encuentro. Si la jurisprudencia ha de proceder caso por caso y atender demandas singulares, debe necesariamente encontrar su apoyo e inspiración en la especificidad ante un problema o un encuentro. Lo que en Diferencia y Repetición se dice sobre el pensamiento vale mutatis mutandis para la ley y la jurisprudencia: “...no hay pensamiento más que involuntario -suscitada violencia en el pensamiento-, tanto más necesario absolutamente que nace, por fractura, de lo fortuito en el mundo (...) No se debe contar con el pensamiento para sentar la necesidad relativa de lo que piensa, sino por el contrario con la contingencia de un encuentro con lo que fuerza a pensar, para levantar y erigir la necesidad absoluta de un acto de pensar, de una pasión de pensar." ${ }^{39}$

El profundo error de la imagen dogmática de la ley -de los defensores de los derechos humanos, de las aplicaciones textuales de legislaciones, por ejemplo- es que reduce el derecho a un conjunto de tesis proposicionales que "tratan" el caso, designan incorrectamente, y que realizan rápidas aplicaciones de la ley original para corregir la situación. ${ }^{40}$ Se pierde el sentido del caso (el problema o el encuentro) como un auténtico

\footnotetext{
${ }^{38}$ Deleuze and Guattari, What is Philosophy?, op. cit., p. 9. [DELEUZE, Gilles, y Guattari, Félix, ¿Qué es la filosofía? Op. cit., p. 13]

39 Deleuze, Difference and Repetition, op cit., p. 139. [DELEUZE, Gilles, Diferencia y Repetición. Op. cit., p. 215]

${ }^{40}$ Para dos exponentes de esta posición, ver Antonin Scalia, A Matter of Interpretation:Federal Courts and the Law (Princeton: Princeton University Press, 1997) ("Lo que busco en la Constitución es precisamente lo que busco en una legislación: el significado original del texto" (38)), y Michael McConnel, "Textualism and Democratic Legitimacy: Textualism and the Dead Hand of the Past" ["Textualismo y legitimidad democrática: textualismo y la opresiva influencia del pasado", in George Washington Law Review 66 (1998): 1127. El textualismo sostiene que el texto legal es la fuente principal de la interpretación legal -por sobre la historia, la doctrina, valores políticos, etc. El originalismo afirma que un particular momento en la historia (el momento originario de la ley en cuestión) debe ser lo determinante en cuestiones de interpretación. En el
} 
elemento genético de la ley. La creación de la ley desde el más íntimo encuentro con un caso no es reducible a estas tesis proposicionales. Una imagen deleuziana de la ley comenzaría sosteniendo que la ley en-sí-misma (el texto mismo de legislaciones, de constituciones, y juicios previos) existe en un letargo del cual sólo se despierta por un encuentro -un caso-, encuentro cuya contingencia la eleva a su necesario ejercicio y a su efectivo poder.

Podríamos dividir los encuentros en dos tipos. El primero es denominado un "caso sencillo." Tal sencillez envenena la imagen dogmática de la ley. En este encuentro, la ley (estatuto, derecho, o decisión previa) está considerada suficientemente clara o suficientemente sólida como para hacer irrelevante el problema genético: i. e., la letra de la ley es aplicada y la sentencia dictada. Siguiendo a Bergson, llamamos a la designación de un "caso sencillo" un corte instantáneo de la memoria-hábito legal. En tal memoria, una "réplica siempre pronta [un hábito] vuelve la pregunta [o el problema] innecesario [inútil]." ${ }^{41}$ Aquí, el caso está condenado a que se le aplique una solución preparada, en la forma de un precedente asentado o de una perspicaz lectura del estatuto. La ley pasa por encima del caso, sirviendo éste último como un simple corte instantáneo o como aplicación. La ley sobrecodifica, "desplaza a la intuición real [i. e., el caso], cuyo papel ya no es entonces otro más que (...) apelar al recuerdo [le souvenir], darle un cuerpo, volverlo activo y por eso mismo actual. ${ }^{\prime 22}$ Desde esta perspectiva, la ley aún requiere un encuentro pero sólo para motivar sus manifestaciones, para reafirmar su dominio en el caso particular. En el caso, la ley gana una específica unidad (una particularidad) para su potencial general; la ley compromete su universalidad para dictar un veredicto en un caso particular, pero al hacerlo realiza un corte instantáneo de su fuerza y su dominio. El caso sencillo mantiene sólo la sombra de su naturaleza genética, reducida a una oportunidad

\footnotetext{
"textualismo" (Scalia) y en el "originalismo" (McConnel) la ley ya está hecha, preformada, preexistiendo a sí misma. Su única acción es pasar a la realidad al tratar adecuadamente el caso que se presenta. Agradezco a Tom Donahue por su ayuda en esto.

${ }^{41}$ Henri Bergson, Matter and Memory, tr. by N.M. Paul and W.S. Palmer (New York: Zone Books, 1988), p 45. [Existe traducción al español: BERGSON, Henri, Materia y memoria. Trad. Pablo Ires. Buenos Aires, Cactus, 2006, p. 58]

${ }^{42}$ Ibid., p 66. [lbíd., p. 78]
} 
transcendental para que la ley obtenga su relevancia y existencia. ${ }^{43}$ Esta aplicación simplemente "habitual" echa a perder la génesis problemática de la ley a partir de un caso para instalar al derecho sobre el caso; la ley se vuelve su propia repetición desnuda o en bruto. Tal caso es verdaderamente no-problemático: su simplicidad (resolubilidad habitual) expresa la emergencia, aplicación, y establecimiento de la imagen dogmática de la ley.

El segundo tipo de encuentro es el "caso problemático", que eleva al encuentro a su función apropiadamente transcendental. El caso sencillo acumulativamente agudiza y genera leyes y decisiones legales ya preparadas, preexistentes. Tal comprensión de la ley, de casos y de problemas pierde de vista todo lo esencial de los procesos legales y de la misma ley. Para comprender cómo funciona la ley debemos asirnos a la naturaleza del problema como aparece en un caso/encuentro. Cuando Bergson o Deleuze afirman que no debemos volvernos esclavos de los problemas, eso no debe confundirse con una cuidadosa selección de problemas empíricos que ocupen nuestra atención (como una corte de revisión judicial ${ }^{44}$ que elige qué casos atender); más bien, debemos comprender la naturaleza genética del problema y evitar recaer en una imagen dogmática con su falsa separación de sentido y enunciación, problema y solución, ley y caso. ${ }^{45}$

Antes de proceder, convendría identificar un cierto número de principios que emergen una vez que el status problemático del caso y de la ley es considerado y analizado. 1. El caso no encuentra una ley preformada o un precedente ya distinguido que

\footnotetext{
${ }^{43}$ Sobre la lógica de la referencia legal vis-à-vis especificidad y generalidad, ver Paul de Man, Allegories of Reading, Figural Language in Rousseau, Nietzsche, Rilke, and Proust (New Haven: Yale University Press, 1979), pp. 267-273; y Georgio Agamben, Homo Sacer: soverign Power and Bare Life, tr. by Daniel HellerRoazen (Stanford: Stanford University Press, 1998), p. 21 [Existe versión castellana: AGAMBEN, Giorgio, Homo sacer I. El poder soberano y la nuda vida. Trad. Antonio Gimeno Cuspinera. Valencia, Pre-Textos, 1998]

${ }^{44}$ [Judicial review (revisión judicial) es un término técnico-jurídico que "refiere a la autoridad del poder judicial de revisar, a veces con la autoridad de anular, los actos de los demás poderes gubernamentales, sean estos legislativos, ejecutivos, o de los tribunales inferiores al que revise". Extraído de http://forum.wordreference.com/showthread.php?t=315781 (N de T.)]

${ }^{45}$ Henri Bergson, The Creative Mind, An Introduction to Metaphysics, tr. By Mabelle L. Andison (New York: Citadel Press, 1974), p. 50. [Existe versión en español: BERGSON, Henri, Introducción a la metafísica. Trad. M. Héctor Alberti. Buenos Aires, Siglo Veinte, 1973, p. 59] DELEUZE, Difference and Repetition,op cit., p. 158. [Deleuze, Gilles, Diferencia y Repetición. Op. cit., p. 242.]
} 
basta para su tratamiento. 2. El encuentro entre ley y caso sirve para conectar los puntos singulares del caso con los puntos singulares de la ley. 3. La conexión de los puntos del caso y de la ley es lo que llamamos jurisprudencia, la práctica del juicio legal. 4. El juicio no está limitado al anuncio de un veredicto: es la construcción de un plano legal, uno en el cual el caso - sus hechos, sus aspectos salientes- es determinado en relación con las leyes $y$, a la inversa, donde las leyes son juzgadas, relacionadas, y transformadas a través de los distintos puntos del caso. 5. Las sentencias legales ( $y$, por eso, la ley) están conectadas con problemas sin los cuales no tendrían sentido. 6. Desestimar o reprimir el status del "problema" lleva a ilusiones de la ley características del primer encuentro. Más aún, si la ley se representa como general y anterior a sus problemas, será debidamente criticada según las cuatro críticas de Deleuze delineadas. 7. Al respetar la naturaleza de este proceso, la jurisprudencia será creativa. La creatividad no es un epíteto aplicado a juicios irregulares sino que es necesaria para sus operaciones de todos los días.

\section{Ley y juicio, sub specie durationis}

Juntos, estos principios constituyen el comienzo de una nueva imagen de la ley. Teniendo esto en cuenta, construiré un escenario jurídico a fin de bosquejar el proceso de la jurisprudencia y la fabricación de una nueva imagen de la ley a partir de conceptos deleuzianos claves. Lo que sigue está, por supuesto, cimentado en Deleuze, pero guarda asimismo una deuda central con Bergson, especialmente con las intuiciones y organización de Materia y Memoria. En ¿Qué es la Filosofía? Deleuze y Guattari rinden tributo a Bergson como el primer autor desde Spinoza en haber construido, con rigurosidad y sin concesiones a la trascendencia, un plano de inmanencia adecuado a la realidad y al pensamiento. ${ }^{46}$ Ellos aluden específicamente al primer capítulo de Materia y Memoria y a su descripción de las imágenes y del movimiento.

\footnotetext{
${ }^{46}$ Deleuze and Guattari, What is Philosophy?, op cil., p. 49. [DELEUZE, Gilles, y GUATTARI, Félix, ¿Qué es la filosofía? Op. cit., p. 52]
} 
En éste capítulo, Bergson establece una teoría de la percepción y del movimiento. Imagina ahí un mundo de pura materia, sin percepción, un mundo de imágenes presentes y no representadas. ${ }^{47}$ Para Bergson, la percepción es sustractiva: aprehendemos pragmáticamente y percibimos sólo los aspectos del objeto que nos interesan. ${ }^{48}$ En consecuencia, una imagen irrepresentada presenta todos sus lados a la vez. Esta imagen existe sin la función reductora de la percepción: está absolutamente presente en todas sus cualidades, aspectos y movimientos, tanto para sí misma como para otras imágenes. Cada "punto" de una imagen es accesible y actúa sobre cada "punto" del universo. Estas imágenes presentes por completo "se presentan recíprocamente todas sus caras [toutes leurs face à la fois], lo que equivale a decir que actúan y reaccionan entre ellas a través de todas sus partes elementales [parties élémentaires], y que ninguna en consecuencia es percibida ni percibe conscientemente. ${ }^{\prime \prime 9}$ El lenguaje resueltamente espacial de Bergson lados, puntos, partes- describe la pura imagen de la materia. Debido a que en esta fase de la teoría el tiempo/duración aún no está incluido, podemos sostener que la imagen es entera y totalmente actual; ella no conserva nada de sí ni en la percepción sustractiva ni tampoco aumenta en duración virtual. Este es un campo en el cual todo está dado (pero no a un sujeto) en infinita reciprocidad.

El caso legal puede ser comprendido como una imagen en este estricto sentido, y puede ser preliminarmente definido como una pura imagen actual en tanto sustente y exceda sus representaciones. Esto nos ayuda a ver que la más básica operación de cualquier juez o abogado es seleccionar puntos y cualidades de un caso legal y coordinarlos en un argumento o juicio. Mientras excluyamos temporalidad y memoria del caso (y en esta instancia lo hacemos), la percepción de un caso y el proceso de presentar un argumento son limitativos y substractivos. Sólo ciertos puntos cruciales son anticipados e interpretados en un argumento legal, pero subyaciendo a estos puntos se encuentra el caso-en-sí-mismo, no percibido, o dando a la percepción la parte que interesa a las partes

\footnotetext{
${ }^{47}$ Bergson, Matter and Memory, op cit., p. 36. [BERGSON, Henri, Materia y memoria. Op. Cit., p. 49]

${ }^{48}$ Ibid., p.21. [lbíd., p. 34]

${ }^{49}$ Ibid., pp. 36-37.[lbíd, p. 51]
} 
percipientes. El caso-en-sí-mismo (el caso puramente actual) tiene una infinidad de puntos y lados que son desestimados, hechos que son irrelevantes para el interés en cuestión que exceden su particular construcción legal. Este caso, entonces, tendrá infinitos puntos y lados. Sus lados presentes actuales son infinitos, disponibles para una posible selección, y sin embargo la infinidad de lados se sostiene sólo en la medida en que estos no sean percibidos. Mientras que es más fácil concebir como una pura imagen actual a un objeto natural que a un caso legal (ya que la definición de éste último como caso legal lo contiene en la percepción y la limitación), afirmamos que en tanto imagen el caso legal existe más completo, absolutamente con más lados, que un caso representado. En este punto de la investigación, el caso legal como imagen actual es una discreta multiplicidad numérica con una infinidad de lados actuales que no conllevan ninguna virtualidad o percepción. El caso no percibido es una actualidad enteramente presente.

Habiendo delineado la pura actualidad de la materia presente espacial, ahora bosquejaré la pura virtualidad de la memoria temporal. Podremos ver que la combinación de estos dos -materia y memoria- proveerá el fundamento para una nueva imagen de la ley. Para Bergson, el concepto de puro pasado emerge de tres paradojas del tiempo. Deleuze analiza estas paradojas con una precisa economía en Diferencia y Repetición. En primer lugar, el pasado no puede ser reconstituido por presentes que pasan, por presentes pasados. Para que el presente pase $-y$ para que exista así una continuidad temporal antes que una serie de instantes presentes yuxtapuestos e infinitamente descomponibles- el presente debe ser "pasado 'al mismo tiempo' que presente." ${ }^{150}$ Esta es la primera paradoja del tiempo: el pasado como contemporáneo del presente que fue. Esto conduce a una paradoja resultante: coexistencia. El presente no coexiste con un pasado discreto; más bien, todo el pasado es contemporáneo con el presente (un presente que, dada la primera paradoja, ahora también es pasado). Finalmente, la tercera paradoja es de la preexistencia. Dado que el pasado es "contemporáneo con el 'presente que ha sido,"' tratamos con un pasado que nunca fue presente, que no fue formado

\footnotetext{
${ }^{50}$ Deleuze, Difference and Repetition, op cit., p. 81. [DELEUZE, Gilles, Diferencia y Repetición. Op. cit., p. 135]
} 
'después,' sino que ya estaba ahí. ${ }^{51}$ Estas tres paradojas conducen a profundas conclusiones sobre la naturaleza del tiempo: existe por lo tanto un "pasado en general" que no es el particular pasado de un particular presente sino que es como un elemento ontológico, un pasado que es eterno y para todo el tiempo, la condición del "pasaje" de cada particular presente. Es el pasado en general lo que hace posible todo pasado. . . Se trata de una memoria inmemorial u ontológica. ${ }^{52}$

Lo que Deleuze llama el "presente actualizado [présent actuel]" es una duración, localizada y actual, que no cesa de pasar y devenir. ${ }^{53}$ No puede decirse que el presente "es," en un sentido ontológico "no es": su naturaleza es devenir y pasar. El puro pasado, por el contrario, es inmutable e inactivo, el ES y es idéntico con el mismo Ser. ${ }^{54}$ Una y otra vez, Deleuze insiste en que el puro pasado no es psicológico sino el fundamento ontológico de un presente actualizado. ${ }^{55}$ Por consiguiente, hasta tanto el puro pasado no es atraído por el presente y actualizado, es el elemento en el cual el presente se establece a sí mismo qua presente pero es el mismo no-actual. Ontológicamente existente, el puro pasado es de otra especie que la imagen actualizada de la materia.

¿Cómo puede contribuir a la nueva imagen de la ley la contemporaneidad del entero pasado con nuestro presente actual? Consideremos “¿Qué es la llustración?” de Kant. Aquí, Kant sostiene que todos llevamos vidas dobles. Por un lado, llevamos adelante vidas "públicas" donde decimos lo que pensamos con el máximo ejercicio de razón posible; por otro lado, ocupamos vidas "privadas" (que podríamos llamar "profesionales") en las que ejercemos roles institucionales, adoptando su proceder. ${ }^{56}$ Volviendo a Bergson,

${ }^{51}$ Ibid., p. 82. [lbid., p. 136.]

52 Deleuze, Bergsonism, op. cit., pp. 56-7. Énfasis propio. [Existe traducción castellana: DELEUZE, Gilles, EI Bergsonismo. Trad. Luis Ferrero Carracedo. Madrid, Cátedra, 1987, p. 57]

${ }^{53}$ Deleuze, Difference and Repetition, op. cit., p. 80. Traducción modificada. [DELEUZE, Gilles, Diferencia y Repetición. Op. cit., p. 132]

${ }^{54}$ Bergson, Matter and Memory, op cit.; p. 150 [BERGSON, Henri, Materia y memoria. Op. Cit., p. 160]; Deleuze, Bergsonism, op. cit. p.54. [DELEUZE, Gilles, El Bergsonismo. Op cit., p. 55]

${ }^{55}$ Keith Ansell-Pearson, Philosophy and the Adventure ofthe Virtual: Bergson and the Time of Life (London: Routledge, 2002), p. 15.

${ }^{56}$ Immanuel Kant, "What Is Enlightenment?" in Practical Philosophy, ed. and tr. by Mary Gregor (Cambridge: Cambridge University Press, 1996). [Existe traducción castellana: KANT, Immanuel, ¿Qué es la ilustración? Y otros escritos de ética, política y filosofía de la historia. Trad. Roberto R. Aramayo. Madrid, Alianza, 2013] 
tomemos el ejemplo de un juez. Considerado como un ser humano (y "público"), un juez obviamente se desplaza dentro del Ser-Memoria, una existencia virtual del pasado que permite actualizaciones de presentes vividos. Pero en sus capacidades como Juez, él ocupa un Ser-memoria institucional, el ser-pasado de la ley. Si bien Bergson no desarrolló esta específica intuición, es posible señalar que no sólo seres vivientes presuponen una pura memoria para su acción presente, sino que las instituciones la presuponen para su funcionamiento.

La ley judicial, en tanto institución, se presta perfectamente para desarrollar esta homología. El juez, como juez, existe dentro de una enorme historia, un pasado institucional, que llamamos memoria archivo. Este archivo es virtual, y, como tal, es el pasado general en el cual se encuentran la totalidad de las decisiones pasadas (precedentes) y estatutos legales disponibles para juzgar. No es una distorsión decir que el "puro pasado," institucionalmente considerado, ofrece un modo de teorizar sobre el puro archivo que permite que el presente actual adquiera relieve. En resumen, en el archivo legal el juez es como el médium del pasado en general y presupone su coexistencia virtual, una existencia ontológica que permite la acción institucional de juzgar.

Seamos muy precisos en esto. Para poder juzgar, un juez debe apelar a un archivo institucional: el aspecto prudencial del juicio exige que éste no ejercite un simple capricho individual sino que esté institucionalmente basado. A fin de que un juicio legítimo se presente a sí mismo (sea como un juicio recordado, o como uno creado) debe enraizarse en la memoria legal. La misma manifestación de un juicio presente reclama una memoriaarchivo coexistente/preexistente; exige que el entero y absoluto archivo legal coexista virtualmente como un médium en el cual discretas decisiones pasadas estén presentes y en el cual el juicio presente pueda él mismo actualizarse. Este archivo no es una mera colección de decisiones individuales y leyes discretas; es el elemento general del pasado que estos recuerdos [souvenirs] presuponen. Es el médium por el cual son preservados para nuestro uso en el juicio presente; es esta pre-existencia del pasado en general (lo que llamamos el archivo de la ley) lo que los recuerdos y, en consecuencia, juicios presentes 
presuponen ${ }^{57}$ Gracias a esto, la teoría de Bergson del puro pasado y de la pura memoria adquiere una vida institucional: el archivo judicial es por entero, aunque virtualmente, presente a un juez que debe juzgar un caso legal realmente presente. El archivo es el Serdel-pasado institucional.

Ahora podemos recorrer en paralelo dos direcciones de la nueva imagen de la ley. Primero, tenemos la imagen del caso puramente positiva y actual que subyace al caso percibido. Tal caso conlleva un infinito número de lados y puntos de los cuales elaboramos una muestra reductora, a fin de dar con el caso legal en tanto representado. Seguidamente, tenemos el archivo virtual, el elemento general del pasado y la totalidad de la memoria institucional de la ley. El archivo es el elemento en el cual puros noactuales existen en relación y continuidad. En esta fase de la indagación, tenemos dos positividades completas, una actual y otro virtual. Ahora vemos la problemática organizadora de la nueva imagen de la ley: ¿cómo hacen la imagen actual del caso y el archivo virtual de la ley para acoplarse entre sí? La solución es la jurisprudencia.

En la pura percepción, la imagen representada es un reflejo de lo interesante, de las posibles acciones ejercidas por el cuerpo sobre la imagen. La pura percepción sin memoria no añade nada creativo a la imagen. ${ }^{58}$ Pero, agrega Bergson, la pura percepción es una ficción heurística: la memoria siempre se añade a la imagen, la memoria siempre acompaña la percepción. ${ }^{59}$ Sin dudas, el aspecto pragmático de la percepción se mantiene - percibimos aquello que es de uso presente, en función de nuestra particular disposición a la acción ${ }^{60}$ - pero esta teoría pragmática de la percepción se ve acrecentada por la

\footnotetext{
57 Gilles Deleuze, Cinema 2: The Time-Image, tr. by Hugh Tomlinson and Robert Galeta (Minneapolis: University of Minnesota, 1989), p. 98. [Existe versión castellana: DELEUZE, Gilles, La imagen-tiempo. Estudios sobre cine 2. Trad Irene Agoff. Buenos Aires, Paidós, 2009, pp. 135-136] Ver también Difference and Repetition, op cit., p. 80: "el pasado en general es el elemento en el cual se enfoca cada antiguo presente en particular y como particular." [DELEUZE, Gilles, Diferencia y Repetición. Op. cit., p. 134]

${ }^{58}$ Bergson, Matter and Memory, op. cit., p 37. [BERGSON, Henri, Materia y memoria. Op. Cit., p. 49]

${ }^{59}$ Ibid., p 232. [lbíd., p. 246]

${ }^{60}$ Bergson afirma que "la conciencia presente admite legalmente sólo esos recuerdos que son de ayuda a la acción." Bergson, "Memory of the presente and false recongnition", en Mind-Energy. Lectures and essays. (New York: Holt and Company, 1920), p. 177. Énfasis añadido. [Existe versión castellana BERGSON, Henry, La energía espiritual. Trad. Pablo Ires. Buenos Aires, Cactus, 2011]
} 
memoria: "la subjetividad cobra, pues, un nuevo sentido que ya no es más motor o material, sino temporal y espiritual: lo que 'se añade' a la materia... la imagen-recuerdo, y no ya la imagen-movimiento., ${ }^{\prime 1}$

En la construcción de un caso y de un proceso legal el primero se ve, en efecto, limitado en términos de sus factores relevantes, o más bien, de los "lados" interesantes que presenta. Pero igualmente, el caso es "aumentado" o creado por una selección llevada a cabo a través del archivo legal. La selección y construcción del caso crea los puntos distintivos de éste último lanzándose al archivo legal y seleccionando recuerdos relevantes requeridos para construir una demanda legal. Este proceso es la construcción de un campo problemático. Sólo con este proceso un "caso" emerge qua caso legal, como un problema: "el problema del pensamiento no está relacionado con la esencia, sino con la evaluación de lo que tiene importancia y de lo que no la tiene, con la distribución de lo singular y lo regular, de lo notable [remarquable] y lo ordinario: que se cumple por entero en (...) la descripción de una multiplicidad, en relación con los acontecimientos ideales que constituyen las condiciones de un 'problema."'62

Los puntos notables y distintos del caso ni preexisten a la ley ni tampoco su definición puede ser discernida sin ella; la esencia de un caso legal es la fabricación de una multiplicidad a partir de significativas resonancias entre caso y archivo. Es esta relación genética entre el caso y el archivo que puede llamarse por igual "argumento legal" o “jurisprudencia” en sí.

Debemos examinar detenidamente cómo son creadas estas resonancias, resonancias que son la esencia de un problema legal. A diferencia de la fórmula de Spinoza del conocimiento intuitivo como sub species aeternitatis, Bergson insiste en que debemos "habituarnos [habitons-nous], a ver todas las cosas sub specie durationis," bajo

\footnotetext{
${ }^{61}$ Deleuze, Cinema 2, op. cit., p. 47. [DELEUZE, Gilles, La imagen-tiempo. Estudios sobre cine 2. Op. cit., p. 72]

62 Deleuze, Difference and Repetition, op. cit. p 189. [DELEUZE, Gilles, Diferencia y Repetición. Op. cit., p. 287]
} 
el aspecto de la duración. ${ }^{63}$ ¿Qué es lo que este mandato requiere? Un salto, sui generis: "por el cual nos desprendemos del presente para resituarnos primero en el pasado en general, luego en una cierta región del pasado - un trabajo de tanteo [de tâtonnement] análogo al enfoque de una cámara fotográfica. Pero nuestro recuerdo queda aún en estado virtual; nos disponemos simplemente a recibirlo adoptando la actitud apropiada [nous nous disposons simplement ainsi à le recevoir en adoptant l'attitude appropriée]. Poco a poco aparece como una nebulosidad que se condensaría; de virtual pasa al estado actual...." ${ }^{64}$

Hasta tanto opere dentro de una tradición de derecho consuetudinario, la jurisprudencia institucionaliza esta actitud: recuerdos particulares (p. ej. un precedente) son rastreados sólo en virtud de este salto y disposición. Para Bergson, la función de la memoria es seleccionar recuerdos a fin de tratar imágenes presentes; para la jurisprudencia, la función del archivo legal es seleccionar precedentes y pautas de la administración pasada de la ley a fin de tratar el caso presente que atiende.

La memoria jurisprudencial procede por tanteo. ${ }^{65} \mathrm{El}$ salto hacia el puro pasado no es el discernimiento de recuerdos actuales sino comienzo de una búsqueda. Para Bergson, esta búsqueda persigue una apropiada tensión. Tal es el sentido del famoso cono del tiempo: el pasado coexiste, total y absolutamente, con nuestro presente en varios grados de contracción y expansión repetidos simultáneamente. Sugiero que el archivo legal (el pasado legal en general) él mismo se repite infinitamente en diferentes grados de contracción y expansión; los diversos planos del puro pasado son "una multitud de repeticiones posibles de la totalidad" del archivo legal. ${ }^{66}$ Mientras más son desplazados los recuerdos del instante presente de acción más preservan su singularidad y distinción; contrariamente, mientras más cerca localicemos un plano respecto del presente activo,

\footnotetext{
${ }^{63}$ Bergson, The Creative Mind, op. cit., pp 128-9. [BERGSON, Henri, Introducción a la metafísica. Op cit., p. 141]

${ }^{64}$ Bergson, Matter and Memory, op. cit., p. 134. Énfasis añadido. Traducción modificada. [BERGSON, Henri, Materia y memoria. Op. Cit., p. 146]

${ }^{65}$ By trail and error. Juego de palabras entre las acepciones de trial: "ensayo", pero también "juicio" ( $N$ de $T$ )

${ }^{66}$ Ibid., p. 168. [BERGSON, Henri, Materia y memoria. Op. Cit., p. 179]
} 
los recuerdos más se asemejan más entre sí y con mayor inmediatez sirven a las necesidades del presente. El salto judicial al archivo legal se lanza hacia el plano de tensión más adecuado a las demandas de juicio del caso actual. "Según el caso, "Deleuze señala" doy un salto a una u otra región del pasado; me instalo en uno u otro nivel; solicito una u otra dominante. ${ }^{\prime 67} \mathrm{Si}$ el plano seleccionado participa de una naturaleza contraída, los recuerdos dentro de tal plano tendrán una naturaleza general y habrán de conectarse con el caso en cuestión fácilmente, incluso habitualmente. Mientras más se expanda el plano, más distinción alcanzarán las cualidades de los precedentes, y se vincularán con problemas específicos de ellos mismos; estos recuerdos serán individualizados con mayor sutileza, pero se aplicarán a los casos a mano con menor inmediatez.

Lo que dificulta comprender la selección es que el puro pasado existe en cada nivel en una continuidad indivisa (aunque en diferentes tensiones) y en cuanto tal impide estrictamente puntos discretos o específicos recuerdos. ¿Cómo hace entonces el plano para dividir y ceder los recuerdos con los cuales se trata el presente? La selección judicial de recuerdos (o precedentes) se cumple a través de traslación y rotación: "la memoria integral responde al llamado de un estado presente a través de dos movimientos simultáneos, uno de traslación, por el cual se presenta entera al encuentro de la experiencia, contrayéndose más o menos de este modo, sin dividirse, en vista de la acción; el otro de rotación sobre sí misma, por el cual se orienta hacia la situación del momento para presentarle su cara más útil [la face la plus utile]."168

Los específicos recuerdos que fracturan un plano de memoria son la función de "rotación," donde un plano presenta su lado más útil, un lado dividido y espacializado. Estas rotaciones son llamadas por necesidades presentes para una específica rememoración, y aun así se dice que el salto selecciona un plano indiviso de tensión utilizable. El salto elige un nivel de tensión indivisa y no un recuerdo específico,

\footnotetext{
${ }^{67}$ Deleuze, Bergsonism, p. 62, op. cit. Enfasis propio. [DELEUZE, Gilles, El Bergsonismo. Op. Cit., p. 63]

${ }^{68}$ Bergson, Matter and Memory, op. cit., p 168. Enfasis añadido. Traducción modificada. [BERGSON, Henri, Materia y memoria. Op. Cit., p. 177]
} 
particionado. Por lo tanto, la búsqueda iniciada por la necesidad presente organiza la memoria virtual en la específica e indivisa tensión que aquella requiere. Este es el trabajo de "traslación," el grado de tensión virtual que contrae o expande un plano de indivisos recuerdos en tensión útil. Traslación (tensión indivisa) y rotación (actualizaciones divididas) son estrictamente simultáneas y necesarias la uno a la otra. El presente presupone de una vez un plano indiviso (que provee un recuerdo con apropiada tensión) y un plano fracturado (en el cual la necesidad presente busca y encuentra recuerdos discretos que encarnan la tensión del todo). La compleja simultaneidad de Bergson es tal que si bien tomamos rememoraciones útiles (rotación) que dividen la tensión virtual, es esta indivisa tensión (traslación) la que ofrece a un adecuado recuerdo contraído y discreto.

Podemos ver ahora cómo el salto judicial expresa la simultaneidad de la traslación y la rotación. Por un lado, un juez puede decidir en un caso según principios generales, amparado por cualquier cantidad de casos sin diferenciar su especificidad (por ejemplo, stare decisis automáticos ${ }^{69}$ y la aplicación de un principio o axioma de un caso testigo ${ }^{70}$, por ejemplo, "primero en tiempo, primero en derecho" para los contratos). Aquí, la totalidad virtual del archivo legal habrá de contraerse tensamente (traslación) de manera tal que un principio general se actualice a partir de él (rotación). Por otro lado, un juez podría desplazarse con mayor profundidad en el cono del tiempo, seleccionando un plano temporal que provea mayor especificidad para seleccionar precedentes y para vincularlos al caso en cuestión. En ambos ejemplos, la específica rememoración disponible para la selección varía según el grado al cual el archivo legal es contraído: cada traslación y rotación del archivo virtual es una integración local de éste de acuerdo con el caso juzgado. Es este proceso lo que actualiza un topos jurisprudencial. Al decir de Bergson, con la variación de cada tensión cada plano se organiza a sí mismo alrededor de renovados

\footnotetext{
${ }^{69}$ Principio legal que exige a las cortes conservar lo ya decidido, ateniéndose a las decisiones precedentes ( $N$ de $T$ )

${ }^{70}$ Leading case en el original: fallo judicial que cambia la doctrina legal de la Corte Suprema de Justicia y sienta nueva jurisprudencia frente a determinada situación. (http://forum.wordreference.com/showthread.php?t=1857331 26/02/11) [N de T]
} 
"recuerdos dominantes" y "puntos brillantes" exclusivos para una tensión particular, puntos capaces de emerger solamente desde esa tensión. ${ }^{71}$ La contracción expresa el movimiento por el cual un recuerdo se actualiza, "al mismo tiempo que el nivel que le es propio." ${ }^{72}$ La jurisprudencia es el proceso que determina la específica tensión del entero archivo legal que es necesaria para juzgar adecuadamente un caso presente, a través de la conexión del caso con la tensión actualizada de un precedente. Esto es lo significa para la jurisprudencia actuar en su propio tiempo y archivo.

\section{La creatividad de la ley}

Valiéndonos de Deleuze y Bergson hemos propuesto una filosofía de la jurisprudencia basada en la repetición de los planos del archivo legal en diversos grados de tensión, una operación que genera el apropiado recuerdo-imagen por el cual un caso legal (un problema legal) es construido. De todos modos, este proceso aún no incluye el rasgo más saliente de la jurisprudencia -la creatividad- con la cual concluiré este ensayo.

Podemos comenzar preguntándonos ¿qué ocurre cuando el reconocimiento falla, cuando las imágenes-recuerdos son insuficientes o están pobremente equipados para tratar un encuentro? Tales fracasos suceden cuando los recuerdos-hábito, nuestro manto de rememoraciones frecuentes, se muestran inadecuados y debemos prolongar una búsqueda de recuerdos, probando varios niveles y tensiones para poder distinguir una imagen adecuada. Como Deleuze observa, ni el reconocimiento atento ni los hábitos nos proveen de un verdadero concepto de memoria; es más bien su perturbación o interrupción lo que revela una genuina capacidad creativa. ${ }^{73}$ Usando un lenguaje kantiano, podríamos decir que cuando falla el juicio determinante de la memoria y el recordar pierde su facultad de subsumir, no nos queda más opción que saltar hacia el archivo: “Si la

\footnotetext{
${ }^{71}$ Bergson, Matter and Memory, op. cit. p. 171 [BERGSON, Henri, Materia y memoria. Op. Cit., p. 179]; Ver también Deleuze, Bergsonism, op.cit., p. 100. [DELEUZE, Gilles, El Bergsonismo. Op. Cit., p. 100]

${ }^{72}$ Deleuze, Bergsonism, op. cit., p. 64. [DELEUZE, Gilles, El Bergsonismo. Op. Cit., p. 65]

${ }^{73}$ Deleuze, Cinema 2, op. cit., p. 54. [DELEUZE, Gilles, La imagen-tiempo. Estudios sobre cine 2. Op. cit., p. 80]
} 
imagen retenida o rememorada [rémemorée] no llega a cubrir todos los detalles de la imagen percibida, se lanza un llamado a las regiones más profundas y alejadas de la memoria, hasta que los demás detalles conocidos vengan a proyectarse sobre aquellos que se ignoran [sur ceux qu'on ignore]. . . nuestra memoria escoge, una tras otra, imágenes análogas diversas que lanza en la dirección de la percepción nueva... ."74

Anteriormente distinguimos dos tipos de encuentros en un caso legal: un así llamado caso "sencillo" tratado por los recuerdos-hábito, y un caso problemático tratado como un problema legal genético. Un caso sencillo se explica sin mayores dificultades por la selección de una imagen recuerdo próxima a la base del cono del tiempo, un hábito judicial determinante que vuelve innecesarias cada indagación en el archivo puro -o cada experimentación con tensión. Por el contrario, un caso problemático no es la expresión de una litigación especialmente compleja; más bien, es una disposición judicial que se atiene a la singularidad del caso vis-a-vis la ley con la cual debe conectar. El problema del caso problemático es descubrir en una percepción legal lo que aún no está legalmente percibido: se trata de conectar el caso en cuestión con puntos del archivo no percibidos previamente, a fin de iluminar puntos del caso no percibidos anteriormente. La memoria y los lados actuales del caso se mueven en vaivén, constituyendo en su recíproca amplificación la fábrica del caso problemático. El reconocimiento fallido inicia la génesis de un problema legal, un caso intratable según los cánones y construcciones habituales. Una disposición favorable al problema legal nos conduce a reinvestigar el archivo, a descubrir recuerdos que al combinarse con el caso generan una verdadera imagen de la ley (caso + archivo jurídico). El respeto por la singularidad del caso no es un llamado trascendente a la justicia y a la infinita otredad; la singularidad es la interrupción del recuerdo-hábito, y una incursión en la inmanencia del Ser-memoria de la ley.

Un caso, hemos visto, presenta una infinidad de lados actuales que, al colocarse en el archivo virtual, se articula con imágenes-recuerdo para generar un apropiado caso

\footnotetext{
${ }^{74}$ Bergson, Matter and Memory, op. cit., pp. 101-2. Traducción modificada. [BERGSON, Henri, Materia y memoria. Op. Cit., p. 114]
} 
legal..$^{75}$ Un caso no actualiza simplemente un plano del archivo legal, sino que se construye el mismo combinando una variedad de recuerdos legales, tomados de diferentes planos con diversa tensión. Este proceso no es diferente a la construcción de un concepto planteada en “¿Qué es la Filosofía?” de Deleuze y Guattari. Ahí, el concepto sobrevuela [survol] sus componentes a una velocidad infinita, y es esto lo que crea la consistencia del concepto. ${ }^{76}$ Igualmente, un caso legal es un singular sobrevuelo de una miríada de imágenes-recuerdo tomadas del archivo legal en una coherente construcción jurisprudencial. Un caso determinado por jurisprudencia contrae un número de momentos externos (externos entre sí en el archivo) en un sólo momento interno, el caso en sí. Vemos ahora como la jurisprudencia crea el caso.

Para finalizar, sostendré una cuestión decisiva: además de crear el caso, la jurisprudencia crea ley y presupone una imagen de la ley que habilita la creatividad y que la exige estructuralmente. En este sentido, deseo valerme de Deleuze tal como Phillipe Soulez usa a Bergson: para insistir en que la creatividad es ella misma un principio político. ${ }^{77}$ Consideremos nuevamente la atenta percepción-imagen: "Un acto de atención implica tal solidaridad entre el espíritu [l'esprit] y su objeto, se trata de un circuito tan bien cerrado, que no se podría pasar a estados de concentración superior sin crear otras tantas piezas [de toutes pieces] con circuitos nuevos que envuelven el primero, y que no tienen en común entre ellos más que el objeto percibido."78

Acabamos de atestiguar este proceso: la percepción atenta no es la combinación de objetos distintos en el mismo plano de memoria; antes bien, es el mismo objeto viajando a través de diferentes planos y aglutinándolos. La travesía de la memoria es rizomática, provocando nuevos cercamientos de los planos en virtud del objeto

\footnotetext{
${ }^{75}$ En este sentido, podemos decir que el caso legal es homólogo a la imagen-cristal de La imagen-tiempo en tanto cada caso qua caso lleva dentro suyo el más pequeño circuito interno entre su actualidad y un archivo legal como pasado virtual. Deleuze, Cinema 2, op cit., pp. 78-83. [DELEUZE, Gilles, La imagen-tiempo. Estudios sobre cine 2. Op. cit., Pp. 110-106]

${ }^{76}$ Deleuze and Guattari, What is Philosophy?, op cit., pp. 15-34. [DELEUZE, Gilles, y GUATTARI, Félix, ¿Qué es la filosofía? Op. cit., pp. 21-38]

${ }^{77}$ Phillipe Soulez, Bergson Politique (Paris: Presses Universitaires de Paris, 1989), p. 280.

${ }^{78}$ Bergson, Matter and Memory, op. cit., p. 104. [BERGSON, Henri, Materia y memoria. Op. Cit., p. 116]
} 
atentamente tratado. Sucesivos planos se unen y cancelan su independencia en esta realidad real y psíquica. ${ }^{79}$ Como Deleuze afirma, "la reciprocidad de la determinación no significa una regresión... sino una verdadera progresión donde los términos recíprocos deben ser ganados poco a poco, y las relaciones mismas deben relacionarse entre ellas." 80 Desde esta perspectiva, la rememoración y las atentas operaciones del archivo de traslación y rotación simultáneamente dan e introducen la diferencia en el presente: cada recuerdo constituye algo nuevo.

La creatividad de la nueva imagen de la ley puede ser estrictamente definida en tres aspectos. Primero, el caso presenta una novedad debido a que combina y unifica varios planos de la ley: el caso actualiza una constelación positiva de planos legales trasladados que llevan tanto el archivo completo y múltiples precedentes rotados seleccionados de diversos niveles de tensión.

En segundo lugar, una jurisprudencia del puro archivo es incapaz de una repetición bruta. Bergson señaló una vez que la biología como ciencia sufre porque le es extraña la idea de absoluta ausencia de repetición. ${ }^{81}$ Tal observación se aplica igualmente al derecho: debido a que los precedentes son elegidos acorde a los distintos puntos del caso, y debido a que los puntos del caso adjudican decisivamente la tensión en la cual el precedente es buscado, sencillamente no hay problema sobre si un precedente "subsuma" o "cubra" el caso. Una imagen dogmática de la ley basada en una diferencia distributiva y en un juicio que divide el caso bajo un criterio dado es tanto un anatema como incompatible con la jurisprudencia creativa que hemos estado describiendo.

En tercer lugar, Bergson y Deleuze repiten a menudo que mientras que la virtualidad del pasado posee una realidad, exige una situación para darle cuerpo y existencia. Es cierto que el caso provee tal actualidad. Lo remarcable del caso es que deviene un problema legal sólo en conexión con un archivo; del mismo modo, la pura ley

\footnotetext{
${ }^{79}$ Deleuze, Cinema 2, op. cit., p. 46. [DELEUZE, Gilles, La imagen-tiempo. Estudios sobre cine 2. Op. cit., p. 70]

${ }^{80}$ Deleuze, Difference and Repetition, op. cit., p. 210. [DELEUZE, Gilles, Diferencia y Repetición. Op. Cit. p. 317]

${ }^{81}$ Henri Bergson, Melanges (Paris: Presses Universitaires de France, 1972), p. 1149.
} 
(el archivo) obtiene realidad sólo cuando es actualizada en un caso. La ley recibe un sentido en el caso: altera su significación según los puntos con los cuales se conecta. Cualquier caso y juicio legal relevantes adaptan el archivo a los lados presentes del caso, y al hacerlo crea un nuevo problema legal y un juicio creativo. ${ }^{82}$ Tal como hemos visto, el caso siempre porta un halo de virtualidad, que permite su construcción como caso; al mismo tiempo y en virtud del mismo proceso las leyes del archivo logran sentido sólo en su diferenciación a través de un caso legal y en su adaptación a un nuevo problema legal.

Por consiguiente, el archivo legal obtiene una vida a través de sus decisiones, adquiere realidad en la selección y adaptación de la jurisprudencia. En consecuencia, la jurisprudencia requiere un derecho repetido diferencialmente en los puros niveles del archivo, y que da a la memoria una apropiada tensión y aplicación. Más aún, la jurisprudencia exige una ley que se someta a la actualización diferencial, al proceso por el cual la ley se actualiza ella misma solamente por transformación, al adoptar las necesidades y problematicidad del caso a mano. Inspirada en los conceptos deleuzianos, la jurisprudencia nos da una adecuada y nueva imagen de la ley acorde a su actuación. La filosofía de Gilles Deleuze nos aporta no sólo una cuidadosa y cuádruple critica de la imagen dogmática de la ley; también nos provee conceptos con los cuales podemos figurarnos una nueva imagen de la ley que se mantiene fiel a la singularidad del caso, que procede según los requerimientos de problemas, que afirma la realidad virtual, y que necesita fundamentalmente creatividad para su desempeño. A fin de funcionar (y esto no es sólo un reclamo ético, sino también ontológico), la ley exige las características de la repetición y actualización diferencial; en otras palabras, la institución de jurisprudencia demanda el ejercicio creativo de la ley para producir así argumentos legales, problemas legales, y procesos legales.

\footnotetext{
${ }^{82}$ Para tomar un ejemplo arbitrario, sino controversial: en Roe v. Wade (1973) el derecho constitucional de privacidad proveniente de decisiones previas tales como Griswold v. Connecticut (1965) se aplicó a la cuestión del aborto. Podemos ver que una rememoración del archivo legal fue adaptada a un nuevo problema legal, transformando de este modo a aquel. Gracias al argumento de Roe, leyes privadas fueron creativamente adaptadas para incluir sustantivos derechos de mujeres. Griswold fue no sólo recordado sino formado en un apropiado nivel de tensión dentro del archivo legal, a fin de ser seleccionado y diferencialmente actualizado en un nuevo caso y problema.
} 